\title{
Changing Status of the Ahom Priestly Class
}

\author{
Dipankar Mohan
}

\begin{abstract}
Human society is the result of a continuous transformation process. In this transformation process religion plays a significant role. In every society customs, beliefs, behaviour, traditions are mostly connected with the religion. So in every society religion and religious traditions became the identity of a society. In case of Assam every tribes had their own priestly class to do priesthood. Similarly the Ahoms had their own priestly class to do priesthood. In this article an attempt has been made to assess the condition of the Ahom priestly class i.e. the Mohan, the Deodhai and the Bailungs.
\end{abstract}

KEYWORDS: tradition, customs, priestly class, priesthood, religion.

\section{INTRODUCTION}

In every society, where there is a religion, a special place was reserved for those who deal with the religious functions, ideologies and customs. In traditional Hindu society where society was divided among the four classes i.e. the Brahmans, Kshatriyas, Vaishyas and Sudras; priesthood is generally ascribed to the Brahmanas. But from society to society it is different from each other. Generally Priestly class refers to the class of people who are associated with the priesthood or priestly activities. The tribes of Assam have their own priestly class to do the priesthood or the priestly activities. Among the Bodo community the Deoris are regarded as the priestly class who performs the priestly activities. In the same way the mibu or deodhai performs the priestly activities among the Mishings. The Dimasas called their priest as Jontaizo who belonged to the priestly class Hojais and all the religious rites were performed by him. Similarly the Karbi has Ojha or Uche as their priestly class. ${ }^{i}$ But the social dignity and status of the caste Hindu priestly class i.e. the Brahmanas had far more higher position than the tribal priests. Like the same, the Tai Ahoms entered the Brahamputra valley, now called Assam valley early in the $13^{\text {th }}$ century with a religion, culture and political system of their own. ${ }^{\text {ii }}$ They brought with them a kind of heterogeneous beliefs and customs which was something new to the social life of early medieval Assam. The Ahoms also had the priestly class to do the priestly activities i.e. Mohan, Deodhai and Bailungs.

\section{METHODOLOGY}

The approach of this study is historical and exploratory in nature. To serve the purpose of the topic, both conventional and analytical methods of investigation are followed. Interviews are also taken for the purpose. However, the facts collected from edited books, journals are also taken

\section{REVIEW OF LITERATURE}

Several works have been done by the researchers on the Ahom community. Some of these important works are:

'Ahomxakolar Utsav Anusthan' by Sukha Baruah draws upon the traditional festivals of the Ahoms in a descriptive way. She has discussed elaborately about the Ahom religious ceremonies such as rikkhan, dam phi, jasingpha, phuralung puja, om pha puja, etc. Moreover she has discussed elaborately about the influence of Hinduism on the Ahoms.

From Padmwshwar Gogoi's book 'Tai Ahom Religion and Customs' we can have brief description of the traditional beliefs and customs of the Ahoms. His, another book, 'The Tai and the Tai Kingdoms' deals the linkage of the Ahoms and other Tai races.

Dr. Birendra Kumar Gohain in his book 'The Ahoms and their Traditions' has given a brief description on the Mohans, Deodhais and the Bailungs. Moreover, it has also given a brief description about traditional Ahom rites and rituals.

\section{DISCUSSION}

Among the Tai-Ahoms, Mohung (Mohan), Changbun (deodhai) and Mo'plong (bailung) are the priestly classes who were entrusted with the duty of rites and rituals in the Ahom period. In the 'Pak Peyn Kaka' which is regarded as the holy text of the Ahoms the following lines were made about them-

“Mo'sham Mo'shai Mo'hung Mo’plong Changbun Kan Tun man.

\section{Sham Mo Myung Wai Yin Kam Tun Man.'}

Meaning: Mohung Moplong Changbun, the three priestly clans of olden times also sprang up from Him, Phra Tyu Ching Phram Hum- the almighty

DIPANKAR MOHAN, M.phill Research Scholar, Department of History Dibrugarh University, E-mail: dipankarmohan44@gmail.com God. ${ }^{\text {iii }}$

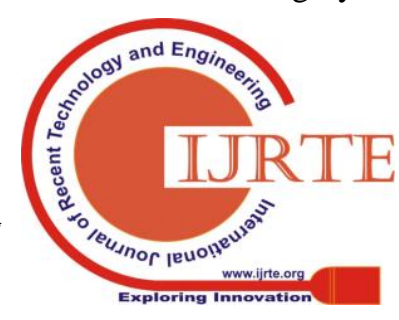


The first Ahom king Sukapha who landed Assam in 1228 was accompanied by Mohan, Deodhai and the Bailungs along with other officials such as Buragohain, Borgohain and other some prominent officers. Mohan, Deodhai and Bailungs are mostly attached with their priestly activities and they were the repository of the vast knowledge of Ahom culture and traditions. From that time onwards, Mohan, Deodhai, Bailung through performing their religious activities helped the Ahom kings in administrative task. In some chronicles attached to the Ahom legend Mohan Deodhai and Bailungs are depicted as ma-lik ma-li which means scholarly people, moru missing which means honorary people and sam ma mung means three main people of country. In initial period of the Ahom rule, Ahom king paid great attention to the works of these people, fellow rulers also put emphasized to run the administration with the help of Mohan, Deodhai and the Bailungs. The Ahoms at the initial period followed their own religion but from the $16^{\text {th }}$ century they started accepting Hinduism and the entire Ahom community became Hindus by the end of the $17^{\text {th }}$ century. During the reign of Sudangpha or Bamuni konwer influence of Hinduism felt in Ahom court. Pratap Singha was the first when Brahmanical Hinduism slowly penetrated inside the Ahom court. Under the influence of Brahmin priests he took Hindu name, the Ahom origin was linked with Hindu god Indra. But Jayadhwaj Singha was the first Ahom king to formally accept Hinduism. Rudra Singha was the first who announced publicly of his inclination towards Hinduism and consequently he became a disciple of a Hindu priest and since then the condition of the three priestly classes got deteriorated. The Mohans, the Deodhais and the Bailungs remained steadfast to their traditional religion.

They are still maintaining the age old traditions, rituals and are still leading their lives professing and practicing the original religions, traditions and culture of the Tai Ahoms. They are still updating their genealogies. ${ }^{\text {iv }}$ The Ahom priestly classes trace their descendant from the Mo'Laokhri, Pujakji and Po phi Su. However Mo'laokhri was the royal priest in the court of Lengdong, Pujakji was the king of Hitkhunban and Po phi su was the progenitor of the Bailung clan. Sukapha was accompanied by Thaomung Mo'sham of the Deodhai clan and Shengkaluk of the Mohung clan. In some buranjis it has been mentioned that the representative of the Bailung clan was already there in Assam. ${ }^{\mathrm{v}}$

There are 7 phoids or clans of Mohans, 12 phoids or clans of the Deodhais, and 18 phoids of the Bailungs. ${ }^{\text {vi }}$

Phoids or clans of the Mohans: Dihingia, Soraimoria, Khanamukhia, Matighoria, Sengelimoria, Rajghoria, Takouboria.

Phoids of Deodhais: Kauriklau (goria), Ba ham ta, Sakoli, Che-pet-ta, Mo sa Ita, Kuk- cha, Dangdeng, Hatiborua, Dhuk la, Khaotek, Mo- ling.

Phoids of Bailungs: Oka, Nora, Poka, Bahboria, Khumtai, Moupia, Kosuhotia, Mothadongia, Safaguria, Dionia, Holguria, Luhotia, Simaluguria, Lefebara, Bortotia, Raidongia, Piraseleka, Dhak-Chowa, Pira-kotia.
Although the majority of the priestly class people inhabit Sivasagar district, some of them are residing in Jorhat district such as Mariaoni, Jhanji, Cheleng. In some parts of the Golaghat district, Dhemaji district, Lakhimpur district and in Guwahati city some of them are living. 'Mohan Deodhai Bailung Sanmilan, Assam' took a census of the priestly class people in 2012. However it was not completed but from the census it can be presumed that population of these people are more than 3. 50. lakhs. ${ }^{\text {vi }}$

\section{A. ROLE OF THE AHOM PRIESTLY CLASS IN AHOM KINGDOM:}

The Ahom Priestly Class i.e. the Mohan, Deodhai and the Bailungs had great role in Ahom kingdom and in the court. Performing religious ceremonies was the main task assigned to them. However, writing buranjis or keep recording political events as well as genealogies of the Ahom kings and other officials such as Buragohain, Borgohain etc. were their other task. They were the preserver of the Ahom tradition as well as the Tai Ahom language. These pundits or molungs had to teach the history, genealogies, culture and politics to the nobles and their sons and at the command of the king, they used to consult the books of astrology and divination, at the time of war or battle, when unnatural events took place when the king dies or whenever a good work was started. ${ }^{\text {vii }}$

Generally the Tai-Ahom Pundits or molungs were household pundits. They never had to give away their day to day family duties in maintaining their religious duties. The molungs or Tai Pundits had to pass several stages before he was given the status of 'molung'. Generally all the important works related to priesthood or priestly activities were done in front of puthi chang and it was a more or less a custom that Tai Pundits should have a puthi chang in their home. ${ }^{\text {ix }}$

After attaining the knowledge of Tai language and other important knowledge from the elderly person of home or from other Tai pundits, they were given the responsibility of copying from original Tai manuscripts. Moreover they were taught about the making of ink, pen or any other important writing material. After this they were given the knowledge about the religious practices, astrology etc. After attaining maturity knowledge about the religious ceremonies they were appointed as helper to the chief molung. Those who attained maturity about this were inspired towards seng hadhona which was regarded as a higher spiritual attainment. ${ }^{\mathrm{x}}$

The molungs used to advise the kings about the perfect time of going to a war, auspicious moment of starting a good work. In the coronation ceremony of a king, the molungs used to empower the royal throne by bringing cheng or divine power to the throne by performing a ritual. They used to study the manuscripts and fortune telling on the legs of a fowl. ${ }^{\mathrm{xi}}$

The molungs were also given the opportunity to discuss important matters in the royal court. If there were important discussion on state 
affairs or any personal discussion, king invited molungs personally. In all important matters their opinion were taken into considerations. ${ }^{\text {xii }}$

They used to take their livelihood from the cultivation. Moreover they took sword whenever there was in need of war or any other external aggression. The chief molung appointed in the royal palace was given paiks and other privileges. They were also appointed in other offices too. In this regard mention may be made of Mosai Sengkaluk who was entrusted in the charge of Tiru Pathar iron ore and in the charge of military department. This was mentioned in the Mohung Vamsavali. ${ }^{\text {xii }}$

The molungs also knew about the use of medicinal plants and penned down the use of medicinal plants on several diseases in Tai scripts. They gave the knowledge of these from generation to generation. ${ }^{\text {xiv }}$

Till the acceptance of Hinduism by the Kings, the Priestly class i.e. the Mohan, Deodhai and the Bailungs played a vital role in administrative as well as spiritual well-being of the kingdom. With the inclination of the Ahom kings towards Hinduism, the Priestly class opposed the acceptance of Hinduism by the kings and resisted the king from doing this. Although the Ahom kings did not totally abandon their traditional customs, rites and rituals, from that time onwards the condition of the Priestly class people did not going well. They somehow become a lone fighter in preserving their traditional religion and customs. They were forced to live a secluded life. After the fall of the Ahom Kingdom and the arrival of the British to Assam, a new era can be noticed about the condition of the Ahoms.

\section{B. CONDITION OF THE AHOM PRIESTLY CLASSS DURING THE BRITISH RULE:}

The British came to power in Assam in 1826 and from that onwards the condition of the Tai-Ahoms became degraded. Although the Ahoms have made several attempts to recapture the power but all their attempts came into vain. In this situation the British made pre planned effort to subjugate the rebellious mind of the Ahoms. After the end of the Ahom rule, the satra Institution became powerful. During the days of the Ahom rule, the satras were gifted thousands acres of lands by the Ahom kings. After the end of the Ahom rule the de facto rule was transferred to the British. With the influence of satras and the conspiracy of the British took a concrete shape when the Ahoms started to take saranas from the satras and thus the satras dominated the Ahoms indirectly. The Ahoms more or less fell prey to the motive of the satras by taking sarans and they inclined a lot towards neo-vaisnavism and gave away their traditional customs and beliefs. Those who accepted Hinduism and saranas had abandoned several traditional beliefs and customs. However in this juncture, the Ahom Priestly Class that is the Mohan, Deodhai and the Bailungs refused to take saranas from the satras and resisted the change by confining them so well that they preserve their own traditional religious customs to a great extent. However all was not gone well for the Mohan, Deodhais and the Bailungs. In this situation the Priestly class become a lone fighter to preserve their original religious customs. On the other hand their condition even deteriorated so badly that they were forced to live a secluded life. Even the Ahoms totally neglected the Mohan, Deodhai and the Bailung clans and the stopped marriage relationship or any other social functions with the priestly class people. They totally boycotted the priestly class people in every matter of social life. They started to neglect the priestly class people for their non acceptance of Hinduism and used derogatory term on them such as aa-sarania, abhogia etc. In this juncture, economic condition of the priestly class deteriorated to even worse.

Due to the deprival of the British and negligence the caste Hindus, the Ahoms began to organize themselves under a common roof and the result of this motive was the formation of Ahom Sabha in 1893. However Ahom Sabha gave more importance on the political aspirations of the Ahoms rather than the issue of Ahom language and religion. In the pre-independence period the Ahom revival movement was carried by the Ahom Sabha but gradually the leaders of the Ahom Sabha got attracted by the national politics of the congress and thus the Ahom movement also got influenced by it. In post-independence era, although several organizations were established but all of them were elite in character and lost its credibility among the masses. In true sense Ahom revivalism took place with the establishment of the Mohan Deodhai Bailung Sanmilan, Assam in 1962. It became the torchbearer of the Ahom revival movement as it took a formidable step to revive the culture of the Ahoms. All the important organizations such as All Assam Phuralung Sangha, Purbanchal Tai Sahitya Sabha etc. were established with the initiative of the Mohan Deodhai Bailung Sanmilan. The Ahom revival movement in the post-colonial period is fully based on the Mohan, Deodhai and the Bailungs as they preserved the Ahom traditional rites and rituals. They are still preserving their traditional rites and rituals to a great extent.

\section{CONCLUSION}

A conclusion section is not required. Although a conclusion may review the main points of the paper, do not replicate the abstract as the conclusion. A conclusion might elaborate on the importance of the work or suggest applications and extensions. Among the Ahoms, the Mohan, Deodhai and the Bailungs are the three clans who perform the traditional rites and rituals. The Ahom king with their arrival in Assam in 1228 performed the traditional Ahom rites and rituals with the help of these priestly class people. In the time being, they mixed with the local people and adopted their rituals under their own domain. However things began to be changed from the 15 th century, with the adoption of Hinduism the kings inclined towards the Hinduism and neglected their own religious traditions. Although they performed some rituals of the Ahom pantheon, the general condition of the Ahom priestly class began to be deteriorated. With the negligence of the kings and the officials, the Ahom priestly class had to live a secluded life. Although the Ahom Priestly Class i.e. Mohans, Deodhais and Bailungs are among the seven royal clans of the Ahom

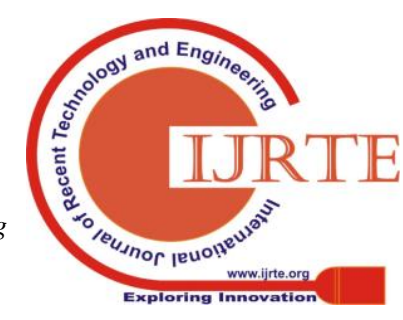


dynasty, they did not get much attention of the Kings due to their non-acceptance of the Hinduism. So, in a vast period of history they have to reside lonely. They are still preserving their traditions to a great extent. But when the revival movement among the Ahoms began, the Priestly Class people soon attracted the attention of the larger section of the Ahom community.

\section{REFERENCES}

[1]. H.K., Barpujari (ed.), The Comprehensive History of Assam, Vol-III Publication Board of Assam, Guwahati, 2007, p.254.

[2]. P., Gogoi, Tai Ahom Religion and Customs, Publication Board of Assam, Guwahati, 1976, p.35.

[3]. B.K., Gohain, The Ahoms and Their Traditions, Vol-I, Omsons Publications, New Delhi, 2011, p.102

[4]. ibid.

[5]. ibid., p.103.

[6]. Interview with Gyanendra Phukan.

[7]. Interview with Manuranjan Phuakn.

[8]. B.K., Gohain, The Ahoms and Their Traditions, Vol-I, Omsons Publications, New Delhi, 2011, p.104.

[9]. Interview with Tileshwar Mohan.

[10]. Lakshminandan, Bora (Ed.), Tai Pandit Tengai Mohung Aru Mohan Deodhai Bailunghokol, Bakata Parijat, 2015, p.30.

[11]. B.K Gohain, op.cit., p.104.

[12]. Lakshminandan, Bora (Ed.), op.cit., p.30.

[13]. Interview with Gyananedra Phukan.

[14]. Lakshminandan, Bora (ed.), op.cit., p.30. 